\title{
Treatment of Overweight and Obesity by Suppressing Intestinal Epithelial Renewal in a Mouse Model of Obesity
}

Wei-ping Zeng ( $\nabla$ weipingzengny@gmail.com )

Therazwimm Corporation

\section{Research Article}

Keywords: obesity

Posted Date: November 4th, 2021

DOI: https://doi.org/10.21203/rs.3.rs-1048419/v1

License: (c) (1) This work is licensed under a Creative Commons Attribution 4.0 International License.

Read Full License 


\title{
Treatment of Overweight and Obesity by Suppressing Intestinal Epithelial Renewal in a Mouse Model of Obesity
}

\author{
Wei-ping Zeng, Ph.D.,
}

${ }^{1}$ Therazwimm Corporation, 3128 Ferguson Road, Huntington, WV 25705

${ }^{*}$ Correspondence: Wei-ping Zeng, Therazwimm Corporation, 3128 Ferguson Road, WV 25705, U.S.A. E-mail: weipingzengny@gmail.com 


\begin{abstract}
Obesity and overweight pose serious risk for many diseases and clinical conditions. However currently available weight loss strategies and pharmacotherapies of obesity are not satisfactory. This study shows that treatments with $\mathrm{pH}$ modifiers such as acids are not only well tolerated by obese mice but also very effective in reducing bodyweight and fat mass by depleting and suppressing the proliferation of proliferating epithelial cells of the intestinal villi. Therefore other cell proliferation inhibitors that suppress intestinal epithelial renewal can also be used for pharmacotherapy of obesity and overweight.
\end{abstract}




\section{Introduction}

According to the World Health Organization (WHO), 39\% and 13\% of the world's adults are overweight or obese, respectively, and over 340 million children and adolescents are overweight or obese based on the data of 2016. (1). Obesity and overweight increase the risk of many serious clinical conditions or diseases such as hypertension, type 2 diabetes, coronary heart disease, stroke, sleep apnea, cancers, clinical depression and pains. (2-4). Obesity and overweight also pose heavy economical burden on society. In the U.S. the medical cost of obesity in adults is estimated at $\$ 342.2$ billion in 2013 dollars. (5).

The prevalence of overweight and obesity has been consistently trending higher. While the increase of the prevalence in developing countries may reflect the adoption of western style high calorie diets, the increase in developed countries such as the U.S. is an indication of the failure of various weight management strategies. (6). With regard to pharmacotherapy of obesity, current drugs are generally not well received by patients because their effects are rather modest and patients often regain body weight after the termination of the medication (7). Given the serious health risk and heavy economical burden of obesity and overweight, novel strategy of developing effective therapy of obesity and overweight is of great significance.

One way to reduce bodyweight is by limiting nutrient absorption. The absorption of nutrients is mainly mediated by the intestinal villi. The intestinal villi are maintained by constant renewal of the epithelial cells including all cell types of the intestinal epithelium through cell proliferation and differentiation. The current study explores a novel strategy of weight control by inhibiting intestinal epithelial renewal thereby limiting nutrient absorption. 
Treatments with $\mathrm{pH}$ modifiers such as organic or inorganic acid preferentially deplete proliferating cells and suppress their proliferation, and the proliferative statuses of the cells are positively correlated with their susceptibility to the depletion and suppression. (Manuscript in preparation). It was therefore further hypothesized that $\mathrm{pH}$ modifiers could be used to inhibit the proliferation hence the renewal of intestinal epithelial cells.

\section{Results}

\section{Reduction of bodyweight and fat mass by in vivo treatments with $\mathrm{pH}$ modifiers}

Obesity was induced in C57BL/6 mice by feeding young female mice with high fat diet for 4 weeks. The mice were then switched to normal diet and randomly divided to groups to receive i.p. injection of saline or saline containing $\mathrm{HCl}, \mathrm{HOAc}$ or $\mathrm{NaOH}$. After the treatments, the saline-treated mice lost about $3 \%$ of body weight due to the change of diet; the $\mathrm{HCl}-$ and HOAc-treated mice lost about $25 \%$ and $15 \%$ of body weight, respectively, whereas the $\mathrm{NaOH}-$ treated mice lost about $17 \%$ of body weight. (Figure 1a).

The fat pads of the mice were analyzed to further determine whether the bodyweight reductions were attributable to the reduction of fat masses. The sizes of fat pads of HCl- and HOAc-treated mice were grossly smaller than those of the saline-treated mice; those of the $\mathrm{NaOH}$-treated mice were also somewhat smaller. (Figure 1b). Fat (weight of all fat pads)/bodyweight ratios of the mice were calculated to normalize the effects of variations of body weight on fat mass. The saline-treated mice had an average fat/bodyweight ratio of 0.135 (13.5\%). The average fat/bodyweight ratios of the $\mathrm{HCl}$ - and HOAc-treated mice were reduced to just $0.027(2.7 \%)$ and $0.045(4.5 \%)$, representing 5- and 3-fold reduction, respectively. On the other hand, despite $17 \%$ of bodyweight reduction, the average fat/bodyweight ratio of the $\mathrm{NaOH}$ - 
treated mice was $0.106(10.6 \%)$, only modestly lower than that of the saline-treated mice. (Figure 1c).

\section{Shortening of intestinal length by treatments with $\mathrm{pH}$ modifiers}

Gross examination of the entire intestines (from the end of stomach to anus) showed that the HCl- and HOAc-treated mice had drastically shortened intestines as compared with the saline-treated mice, whereas the intestines of the NaOH-treated mice were only slightly shortened. (Figure 2a). Quantitative measurements found that the HCl- and HOAc-treated mice had on average about $31 \%$ and $12 \%$ reduction of intestinal lengths, respectively, whereas the $\mathrm{NaOH}$-treated mice had only about $2 \%$ reduction. (Figure $2 \mathrm{~b}$ and $\mathrm{c}$ ).

\section{No significant reduction of masses of other major abdominal organs}

Despite the significant reduction of body weights and shortening of the intestines, the masses of the other two major abdominal organs the livers and kidneys were similar among the different treatment groups. (Figure $3 \mathrm{a}$ and $\mathrm{b}$ ).

\section{Acid treatments reduced proliferating cells in the intestinal villi}

To determine whether the fat mass reduction and shortening of the intestines were related to depletion of proliferating intestinal epithelial cells, tissue sections of intestines of representative mice of the different treatment groups were stained for Ki-67 with hematoxylin counter staining. Ki-67 is a reliable marker for proliferating cells, its level of expression positively correlates with rRNA and DNA synthesis. (8). As shown in Figure 4, there were more $\mathrm{Ki}-67^{+}$cells in the intestinal villi of saline- or $\mathrm{NaOH}$-treated mice than in the HCl- or HOActreated mice. In addition, the Ki-67 staining was the strongest in the $\mathrm{NaOH}$-treated mice, followed by that of the saline-treated mice, which was in turn stronger than those of the $\mathrm{HCl}-$ or 
HOAc-treated mice. Thus, acid treatments depleted proliferating cells and inhibited cell proliferation, whereas alkaline treatment enhanced cell proliferation in the intestinal villi.

\section{Discussion}

This study shows that $\mathrm{pH}$ modifiers can potentially be used for pharmacotherapy of obesity and overweight. While all three $\mathrm{pH}$ modifiers tested in this study, $\mathrm{HCl}, \mathrm{HOAc}$ and $\mathrm{NaOH}$ caused significant weight loss, acid treatments were particularly effective in reducing fat/bodyweight ratios. $\mathrm{HCl}$ treatments showed the strongest effects on bodyweight and fact mass reduction, and caused dramatic shortening of the intestines. On the other hand, while HOAc treatments also led to substantial reduction of bodyweight and fat mass, they caused only modest shortening of the intestines. The effects of the acid treatments appeared to be related to the depletion of proliferating cells in the epithelium of the intestinal villi and suppression of the proliferation. In contrast, $\mathrm{NaOH}$ treatments enhanced or at least maintained the proliferation of the intestinal epithelial cells. Such dichotomy of effects on cell proliferation and death is consistent with the notion that cell death and proliferation are controlled by a $\mathrm{pH}$ balance such that low $\mathrm{pH}$ induces cell death by apoptosis whereas high $\mathrm{pH}$ promotes cell proliferation. (Manuscripts in preparation).

While the current study tested only three $\mathrm{pH}$ modifiers of simple acids and base, it can be reasonably extrapolated that other organic or inorganic acids or bases, as well as $\mathrm{pH}$ buffering agents, may have similar effects. Further, $\mathrm{pH}$ modifiers may also include ionophores and stimulators or inhibitors of the expression or activities of enzymes, membrane transporters or ion channels that are responsible for the maintenance or alteration of $\mathrm{pH}$ in or around an intestinal 
epithelial cell. For examples, some of such enzymes and membrane transporters may include carbonic anhydrases, monocarboxylate transporters, proton or bicarbonate transporters. (9-18).

Based on the current study, it can also be expect that any cell proliferation inhibitors that reduce intestinal epithelial renewal could potentially be repurposed for pharmacotherapy of obesity and overweight. Such cell proliferation inhibitors can be general cell proliferation inhibitors or inhibitors of the signaling pathways operating in the crypt of the intestinal villus. The former could be inhibitors and antagonists of DNA synthesis, cyclin-dependent kinases (CDKs) and Myc. (19-24). The latter could be inhibitors and antagonists of the Wnt- $\beta$-catenin signaling pathway, the EGFR signaling pathway and the Notch signaling pathway. (25-31).

\section{Materials and Methods}

Mice. Female C57BL/6 mice were purchased from Jackson Laboratory (Bar Harbor, ME, USA), and housed in the animal facility of Charles River Accelerator and Development Lab (CRADL) (Cambridge, MA, USA). Animal studies were performed according to the protocols approved by the CRADL Institutional Animal Care and Use Committee.

Obesity model. The obesity model was similar to those previously described. $(32,33)$. Female C57BL/6 mice of 4 weeks age were first acclimated at CRADL for 1 week. After the acclimation, mice were switched to Gamma-irradiated high fat diet (Research Diets, New Brunswick, NJ, USA) (60\% calories from fat) for 4 weeks.

Treatments with $\mathrm{pH}$ modifiers. After 4 weeks of high fat diet, the obese mice were switched back to regular diet, and randomly divided into 4 groups to receive i.p. injection of $200 \mu \mathrm{l}$ saline or saline plus $87.5 \mathrm{mM} \mathrm{HCl}, \mathrm{HOAc}$ or $\mathrm{NaOH}$. The bodyweight of each mouse was recorded before each treatment. The mice continued to receive the treatments every other day 
for 3 times. Four days after the final treatments, mice were sacrificed, their total body weights were measured, fat pads, and internal organs were collected, weighed, and analyzed.

Ki-67 immunohistochemistry. One day after 3 treatments with the $\mathrm{pH}$ modifiers, mice were sacrificed and intestines were fixed in $10 \%$ neutral formalin. Segments of the fixed jejunums were paraffin embedded and sectioned. Ki-67 staining of the tissue sections was carried out as described. (34). Briefly, after de-paraffinized and rehydrated, the tissue sections were heated in $10 \mathrm{mM}$ Sodium Citrate Buffer, $\mathrm{pH}$ 6.0, to boiling, followed by washing with PBS and incubation in $10 \% \mathrm{H}_{2} \mathrm{O}_{2}$ at room temperature for 15 minutes. The tissue sections were then blocked with 5\% BSA, and incubated with rabbit anti-mouse Ki-67 antibody (Servicebio, Wuhan, China) in PBS at $4^{\circ} \mathrm{C}$ overnight. After washing with PBS plus $0.1 \%$ Tween 20 , the tissue sections were incubated with Horseradish Peroxidase (HRP)-conjugated goat anti-rabbit antibodies (Invitrogen, Carlsbad, CA, USA) at room temperature for $1 \mathrm{hr}$. After washing the slides, color deposits were developed using a DAB Substrate Kit (ThermoFisher, Waltham, MA, USA) according to the manufacturer's instructions. After color was developed, the slides were washed with $\mathrm{ddH}_{2} \mathrm{O}$, and counter-stained with hematoxylin. The slides were scanned, and images were analyzed with QuPath software (https://qupath.github.io).

\section{Declaration}

The author declares no conflict of interest.

\section{Figure Legends}

Figure 1. Reduction of body weights and fat masses in obese mice by $\mathrm{pH}$ modifiers. (a) Graph showing the average percentages of bodyweight reduction after treatments with different 
pH modifiers as indicated. (b) Photographs of fat pads comparing the sizes of the fat pads of representative mice of the different treatment groups. (c) Graph showing the average fat/bodyweight ratios of the mice in the treatment groups. Statistical significance of the differences of bodyweight reduction and fat/bodyweight ratios between saline group and the other treatment groups was determined by Student $\mathrm{t}$ test. ${ }^{* *}, p<0.01$. Data were pooled from 3 experiments.

Figure 2. Reduction of intestinal length by $\mathrm{pH}$ modifiers. (a) Photographs of the entire intestines of representative mice of the different treatment groups. (b) Graph showing the average lengths of the intestines of mice of the different treatment groups. Statistical significance of differences between saline group and other treatment groups was determined by Student t test. ${ }^{* *}, p<0.01$. (c) Graph showing the average percentages of reduction of the intestinal length of the acid- or alkaline-treated mice as compared with the saline-treated mice.

Figure 3. Effects of $\mathrm{pH}$ modifiers on the masses of livers and kidneys. (a and b) Graphs showing average weights of livers (a) and kidneys (b) of mice in the different treatment groups.

Figure 4. Modulation of cell proliferation in the epithelium of the intestinal villi by $\mathrm{pH}$ modifiers. Microscopic views of intestinal tissue sections stained for Ki-67 (brown) with haematoxylin counter staining (blue) of representative mice of the different treatment groups.

\section{References}

1. Organization WH. 2021. Obesity and overweight. https://www.who.int/news-room/factsheets/detail/obesity-and-overweight. Accessed October 26, 2021. 
2. Bhaskaran K, Douglas I, Forbes H, dos-Santos-Silva I, Leon DA, Smeeth L. 2014. Bodymass index and risk of 22 specific cancers: a population-based cohort study of 5.24 million UK adults. Lancet 384:755-65.

3. Jensen MD, Ryan DH, Apovian CM, Ard JD, Comuzzie AG, Donato KA, Hu FB, Hubbard VS, Jakicic JM, Kushner RF, Loria CM, Millen BE, Nonas CA, Pi-Sunyer FX, Stevens J, Stevens VJ, Wadden TA, Wolfe BM, Yanovski SZ, American College of Cardiology/American Heart Association Task Force on Practice G, Obesity S. 2014. 2013 AHA/ACC/TOS guideline for the management of overweight and obesity in adults: a report of the American College of Cardiology/American Heart Association Task Force on Practice Guidelines and The Obesity Society. J Am Coll Cardiol 63:2985-3023.

4. Luppino FS, de Wit LM, Bouvy PF, Stijnen T, Cuijpers P, Penninx BW, Zitman FG. 2010. Overweight, obesity, and depression: a systematic review and meta-analysis of longitudinal studies. Arch Gen Psychiatry 67:220-9.

5. Biener A, Cawley J, Meyerhoefer C. 2017. The High and Rising Costs of Obesity to the US Health Care System. J Gen Intern Med 32:6-8.

6. Hales C, Carroll M, Fryar C, Ogden C. 2020. Prevalence of Obesity and Severe Obesity Among Adults: $\quad$ United $\quad$ States, $2017-2018$. https://www.cdc.gov/nchs/products/databriefs/db360.htm. Accessed October 27, 2021.

7. Heymsfield SB, Wadden TA. 2017. Mechanisms, Pathophysiology, and Management of Obesity. N Engl J Med 376:1492.

8. Darzynkiewicz Z, Zhao H, Zhang S, Lee MY, Lee EY, Zhang Z. 2015. Initiation and termination of DNA replication during $\mathrm{S}$ phase in relation to cyclins D1, E and $\mathrm{A}$, 
p21WAF1, Cdt1 and the p12 subunit of DNA polymerase delta revealed in individual cells by cytometry. Oncotarget 6:11735-50.

9. Benassi A, Doria F, Pirota V. 2020. Groundbreaking Anticancer Activity of Highly Diversified Oxadiazole Scaffolds. Int J Mol Sci 21.

10. Ch'en FF, Villafuerte FC, Swietach P, Cobden PM, Vaughan-Jones RD. 2008. S0859, an $\mathrm{N}$-cyanosulphonamide inhibitor of sodium-bicarbonate cotransport in the heart. $\mathrm{Br} \mathrm{J}$ Pharmacol 153:972-82.

11. Felmlee MA, Jones RS, Rodriguez-Cruz V, Follman KE, Morris ME. 2020. Monocarboxylate Transporters (SLC16): Function, Regulation, and Role in Health and Disease. Pharmacol Rev 72:466-485.

12. Lugini L, Federici C, Borghi M, Azzarito T, Marino ML, Cesolini A, Spugnini EP, Fais S. 2016. Proton pump inhibitors while belonging to the same family of generic drugs show different anti-tumor effect. J Enzyme Inhib Med Chem 31:538-45.

13. Meleddu R, Deplano S, Maccioni E, Ortuso F, Cottiglia F, Secci D, Onali A, Sanna E, Angeli A, Angius R, Alcaro S, Supuran CT, Distinto S. 2021. Selective inhibition of carbonic anhydrase IX and XII by coumarin and psoralen derivatives. J Enzyme Inhib Med Chem 36:685-692.

14. Mihaila RG. 2015. A minireview on NHE1 inhibitors. A rediscovered hope in oncohematology. Biomed Pap Med Fac Univ Palacky Olomouc Czech Repub 159:51926.

15. Scozzafava A, Supuran CT. 2002. Carbonic anhydrase activators: human isozyme II is strongly activated by oligopeptides incorporating the carboxyterminal sequence of the bicarbonate anion exchanger AE1. Bioorg Med Chem Lett 12:1177-80. 
16. Temperini C, Scozzafava A, Vullo D, Supuran CT. 2006. Carbonic anhydrase activators. Activation of isozymes I, II, IV, VA, VII, and XIV with 1- and d-histidine and crystallographic analysis of their adducts with isoform II: engineering proton-transfer processes within the active site of an enzyme. Chemistry 12:7057-66.

17. Whitton B, Okamoto H, Packham G, Crabb SJ. 2018. Vacuolar ATPase as a potential therapeutic target and mediator of treatment resistance in cancer. Cancer Med 7:38003811.

18. Bulli I, Dettori I, Coppi E, Cherchi F, Venturini M, Di Cesare Mannelli L, Ghelardini C, Nocentini A, Supuran CT, Pugliese AM, Pedata F. 2021. Role of Carbonic Anhydrase in Cerebral Ischemia and Carbonic Anhydrase Inhibitors as Putative Protective Agents. Int J Mol Sci 22.

19. Berdis AJ. 2017. Inhibiting DNA Polymerases as a Therapeutic Intervention against Cancer. Front Mol Biosci 4:78.

20. Duffy MJ, O'Grady S, Tang M, Crown J. 2021. MYC as a target for cancer treatment. Cancer Treat Rev 94:102154.

21. Ingham M, Schwartz GK. 2017. Cell-Cycle Therapeutics Come of Age. J Clin Oncol 35:2949-2959.

22. Madden SK, de Araujo AD, Gerhardt M, Fairlie DP, Mason JM. 2021. Taking the Myc out of cancer: toward therapeutic strategies to directly inhibit c-Myc. Mol Cancer 20:3.

23. Parker WB. 2009. Enzymology of purine and pyrimidine antimetabolites used in the treatment of cancer. Chem Rev 109:2880-93.

24. Qin Q, Ren Y, Zhong D. 2020. [Research Progress of CDK4/6 Inhibitors in Non-small Cell Lung Cancer]. Zhongguo Fei Ai Za Zhi 23:176-181. 
25. Ballweg R, Lee S, Han X, Maini PK, Byrne H, Hong CI, Zhang T. 2018. Unraveling the Control of Cell Cycle Periods during Intestinal Stem Cell Differentiation. Biophys J 115:2250-2258.

26. Merenda A, Fenderico N, Maurice MM. 2020. Wnt Signaling in 3D: Recent Advances in the Applications of Intestinal Organoids. Trends Cell Biol 30:60-73.

27. Pinto D, Gregorieff A, Begthel H, Clevers H. 2003. Canonical Wnt signals are essential for homeostasis of the intestinal epithelium. Genes Dev 17:1709-13.

28. Suzuki A, Sekiya S, Gunshima E, Fujii S, Taniguchi H. 2010. EGF signaling activates proliferation and blocks apoptosis of mouse and human intestinal stem/progenitor cells in long-term monolayer cell culture. Lab Invest 90:1425-36.

29. Harb J, Lin PJ, Hao J. 2019. Recent Development of Wnt Signaling Pathway Inhibitors for Cancer Therapeutics. Curr Oncol Rep 21:12.

30. Xu MJ, Johnson DE, Grandis JR. 2017. EGFR-targeted therapies in the post-genomic era. Cancer Metastasis Rev 36:463-473.

31. Zhong F-F, You Y, Liu W-J. 2021. Progress in research on childhood T-cell acute lymphocytic leukemia, Notch1 signaling pathway, and its inhibitors: A review. Bosn J Basic Med Sci 21:136-144.

32. Incio J, Liu H, Suboj P, Chin SM, Chen IX, Pinter M, Ng MR, Nia HT, Grahovac J, Kao S, Babykutty S, Huang Y, Jung K, Rahbari NN, Han X, Chauhan VP, Martin JD, Kahn J, Huang P, Desphande V, Michaelson J, Michelakos TP, Ferrone CR, Soares R, Boucher Y, Fukumura D, Jain RK. 2016. Obesity-Induced Inflammation and Desmoplasia Promote Pancreatic Cancer Progression and Resistance to Chemotherapy. Cancer Discov 6:852-69. 
33. Martinez-Huenchullan SF, McLennan SV, Ban LA, Morsch M, Twigg SM, Tam CS. 2017. Utility and reliability of non-invasive muscle function tests in high-fat-fed mice. Exp Physiol 102:773-778.

34. Crosby K, Standen C. 2014. Immunohistochemistry Protocol for Paraffin-embedded Tissue Sections. JOVE doi:10.3791/5064. 
a)

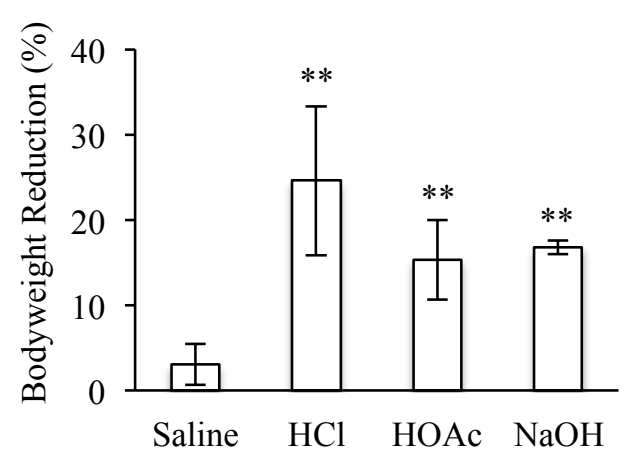

b)

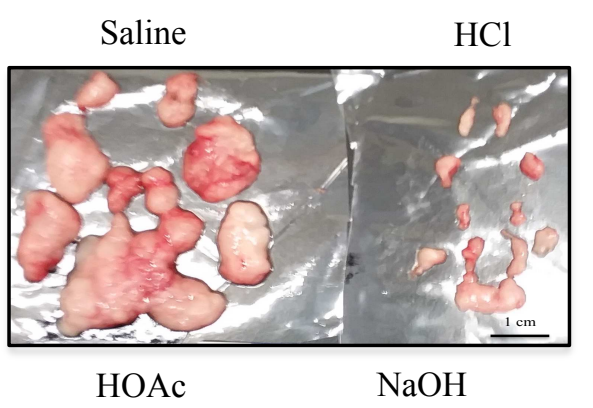

c)

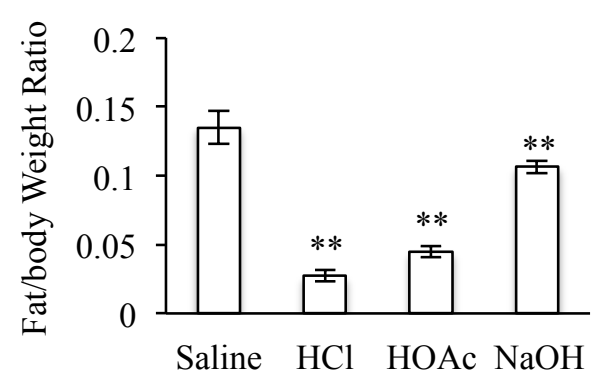


a)

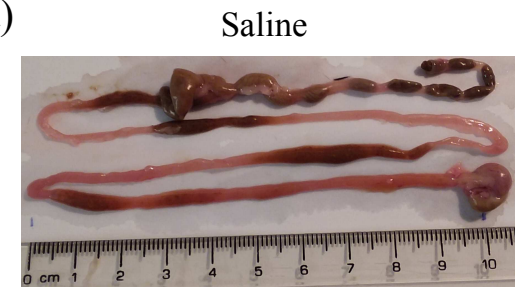

HOAc

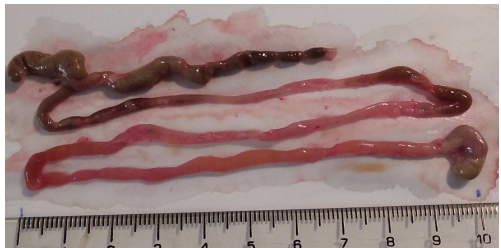

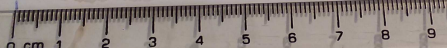

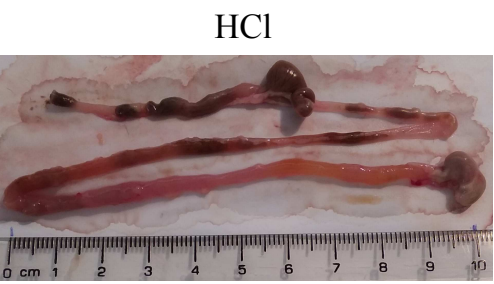

$\mathrm{NaOH}$

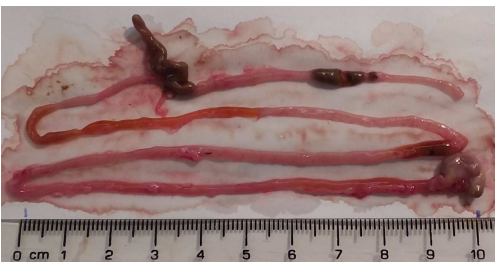

b)

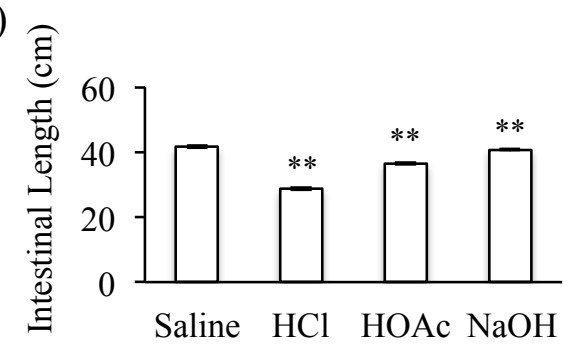

c)

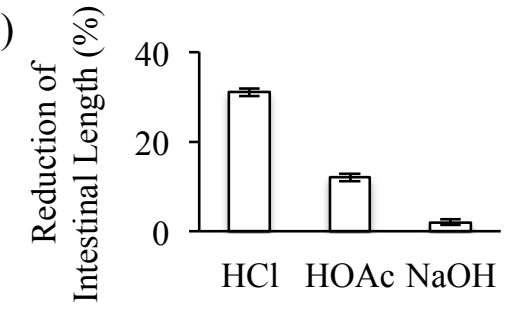



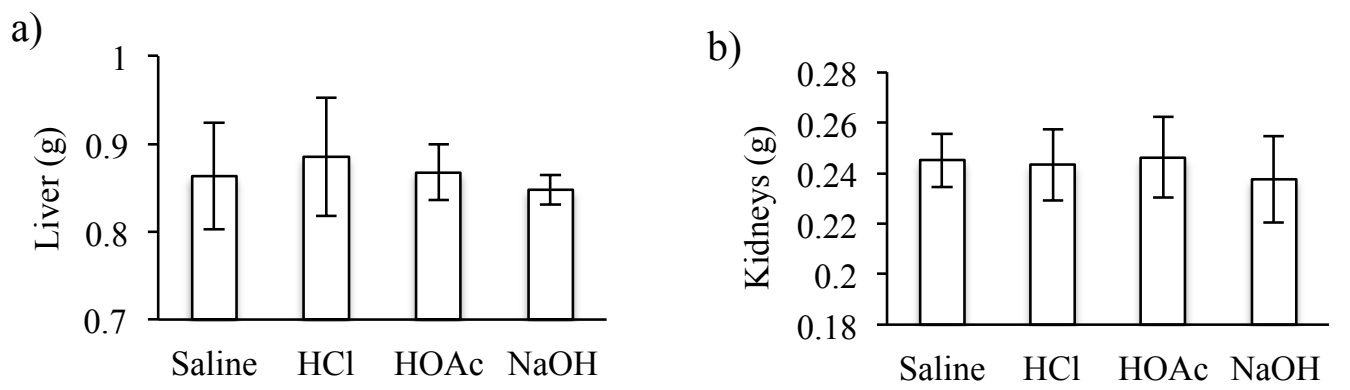


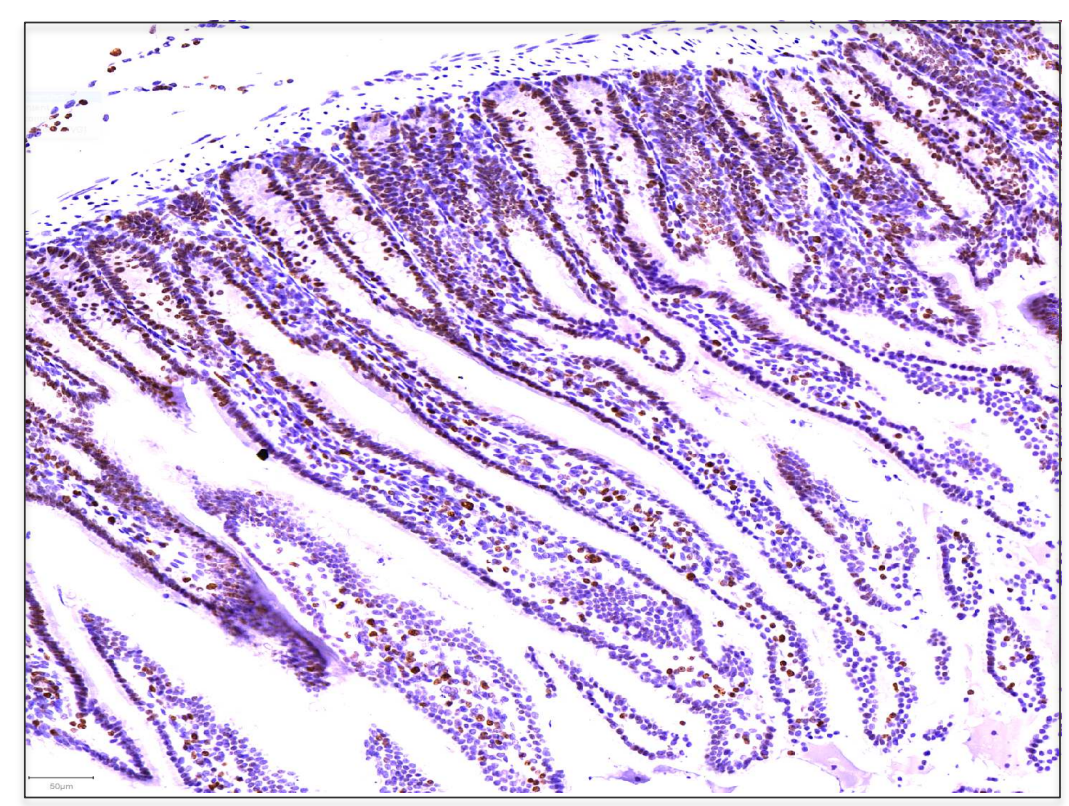

HOAc

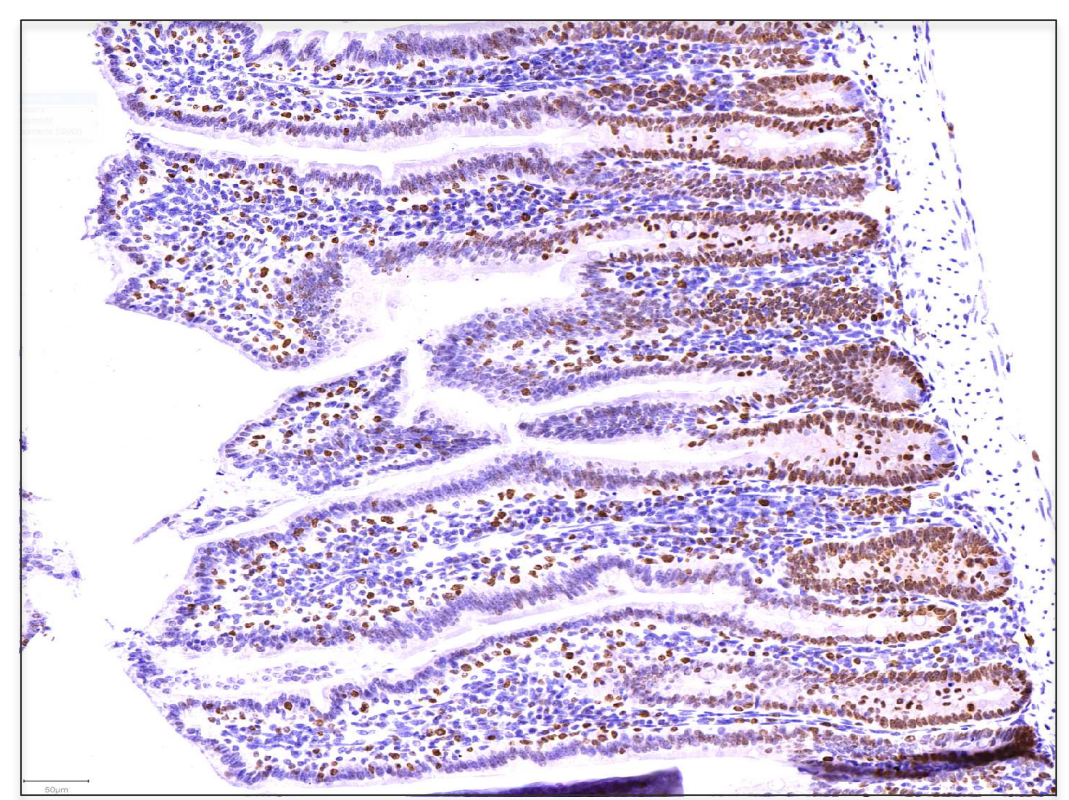

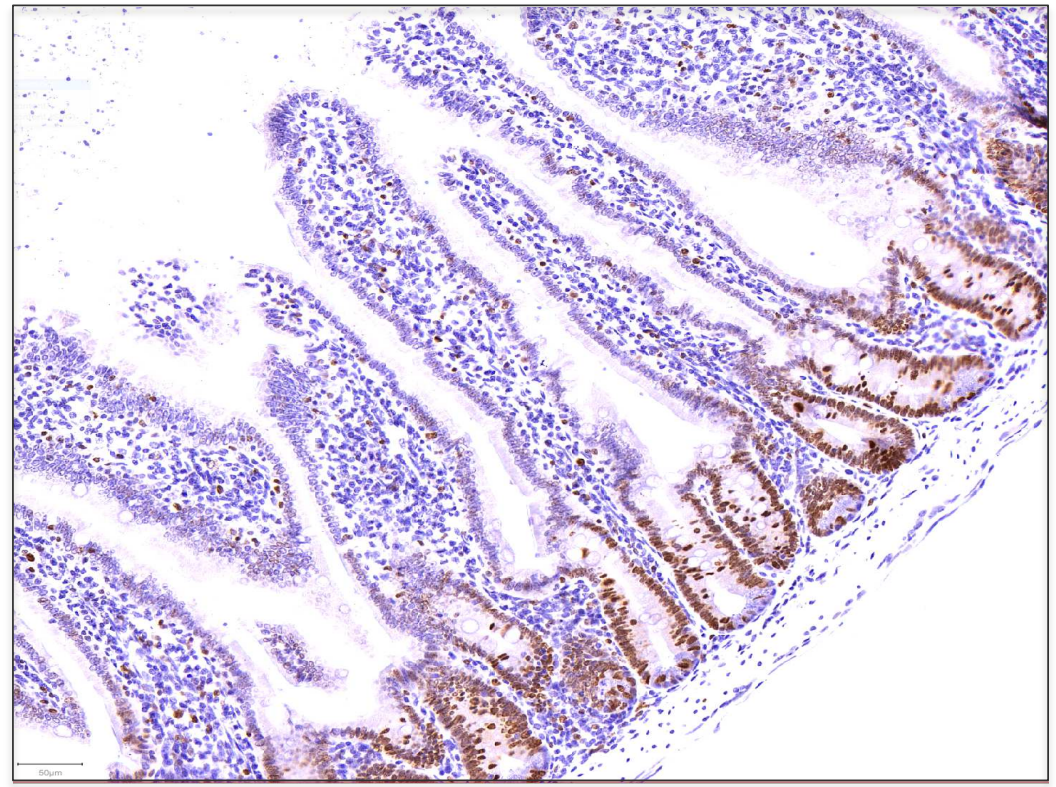

$\mathrm{NaOH}$

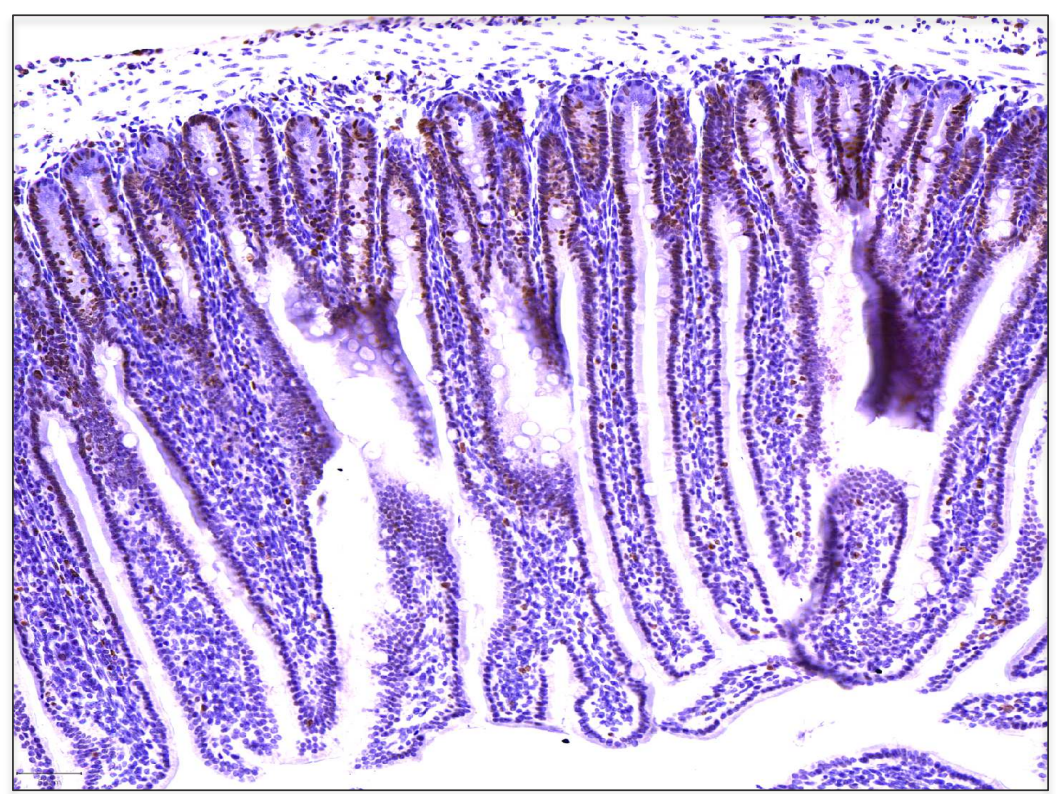

